\title{
Study on the Effect of Modern Educational Technology on Quality Education
}

\author{
Yingying Sun ${ }^{1, a}$ \\ ${ }^{1}$ School of Information Technology and Media, Beihua University, Jilin, China 132013 \\ awsyy_9@126.com
}

\begin{abstract}
Keywords: Modern educational technology; Quality education; Educational reform
\end{abstract}
\begin{abstract}
Modern educational technology is the product of the combination of advanced education thought and advanced science and technology. It is the sum of all the technical means adopted by human beings in educational activities, while quality education is the key content of China's education system reform. This article aims to study how to use modern education technology to promote the further development of quality education, taking how to use modern educational technology to deepen the educational reform, how to use modern education technology to cultivate innovative talents and the sustainable development of talent as the starting point, discussed the important role of the modern education technology in quality education.

With the rapid development of science and technology, the modern educational technology with the core of information technology application has been widely used in the actual education and teaching process, and has become an important means of modern distance education, social education and lifelong education. In our country, the Ministry of Education issued "The Decision on Deepening the Educational Reform to Promote the Quality Education in an All-round Way" to promote the transformation of our school education and training objectives from "exam-oriented education" to "quality-oriented education", focusing on cultivating students' practical ability and the courage to innovate, and then gradually improve the overall quality of students, and thus promote the real implementation of quality education.
\end{abstract}

\section{Modern Educational Technology}

What is Modern Education Technology? Modern education technology is a new branch of education, based on modern teaching theory as a guide and science and technology as a means, scientifically integrating teaching process and learning resources, the theory and practice of achieving the purpose of teaching optimization. Modern education technology emphasizes the improvement of traditional teaching methods and teaching skills, pay attention to the rational use of teaching media in the teaching process, optimize the teaching process, and thus improve the quality of education and teaching. The scientific application of modern educational technology in practical teaching has made great changes in teaching communication methods, teaching content presentation methods, teaching methods and teaching organization forms, and has led to fundamental changes in the related educational concepts, educational system and so on, breaking the traditional education model, pooling a new era of breath into the entire education and teaching process.

The Influence of Modern Educational Technology on Education.

1) The high efficiency and high quality of modern educational technology in information storage, transmission and presentation can make the learners in different places communicate with teachers through the Internet and through satellite transmission and interactive TV. The traditional class teaching system model, teaching activities and teaching organization produce a fundamental change.

2) Modern educational technology can take scattered teaching content and teaching examples together and form a system to optimize the teaching content and teaching process, and then improve teaching efficiency and teaching quality. 
3) Modern educational technology using media tools to simulate the reality, to solve abstract teaching content in the traditional teaching process, making the whole learner in learning process has a strong intuitive and self-operation, conducive to learners to carry out image understanding analysis, so that learners in their learning process tends to take the initiative, in a dominant position.

4) Modern educational technology can realize the two-way interaction between teachers and learners in the process of teaching and learning. Learners use their computers to develop their own learning methods according to their own learning habits. Teachers use the specific teaching software to evaluate learners' learning results. It fundamentally realized the differentiation of learners' learning, and embodied the teaching principles of "teaching students in accordance with their aptitude".

5) Modern educational technology using a variety of modern communication technology for information exchange and transmission, so that modern distance learning become possible. Not limited to time and space, learners can through the network to learn effectively, significantly reducing learning costs.

\section{Using Modern Educational Technology to Promote Quality Education}

Theoretical Basis Modern educational technology has a wide range of performance skills, can provide students with a wealth of perception of the material, and teaching ideas and teaching links are fully reflected in the classroom teaching, to stimulate students 'learning motivation, and interest in actively participating in teaching activities, to expand the students' direct experience, lively and specifically express teaching content, reflecting the inherent attributes of things, providing a wealth of materials for the students' cognitive activities, conducive to students to learn and master knowledge. At the same time, the flexible use of multimedia technology in modern educational technology can stimulate students' different senses. At the same time, enhance the image, fun and comprehension of teaching content, so that students' cognitive activities produce from shallow to deep level, from emotion to ration, to mobilize the enthusiasm of students to learn, lead students to actively think and practice, and ultimately achieve a good educational effect.

\section{The Problems need to be Paid Attention to.}

1) Do not change the teacher's dominant position

Compared with traditional education teaching methods, the advantages of the modern educational technology teaching is obvious, but still can not ignore the dominant position of teachers in the teaching process. In the actual teaching process, the outstanding teachers' vivid explanation, concise writing on the blackboard and the timely exchange of feedback between teachers and students are very necessary. These are the methods for students to take the initiative to participate in the teaching process is irreplaceable. If the teacher in the actual classroom teaching process lost its dominant position, it will greatly reduce the actual teaching effect. Therefore, in the actual teaching process, it will be clear of the teacher-led, student-centered teaching model. The key to teaching is that teachers should be based on the previous teaching work to carefully prepare lessons, make system design and correct use modern educational technology.

2) The correct positioning of courseware content

In the process of making and using multimedia teaching courseware, teachers can not blindly abuse courseware for teaching content or blackboard content in the whole course and regardless of all the courseware into the classroom. This kind of teaching courseware often lose focus, difficult to define unclearly, students can not master the key knowledge. Therefore, in the process of courseware, they should pay attention to applicability and practicality, should be based on the syllabus and teaching objectives as the basis, correctly grasp the age characteristics and cognitive laws of students, highlighting the teaching focus and teaching difficulties, so that the objectives is clear, to achieve the desired teaching effect. 


\section{The Role of Modern Educational Technology in Quality Education}

Modern Education Technology can Solve the Core Problem of Quality Education The core problem of quality education is the reform of teaching mode. At present, China's education and teaching mode is still the "teaching" -based traditional teaching model, while modern educational technology can play a great role in this teaching mode, and can promote the transformation of "teaching" teaching model to the main mode of "learning". The integration of multimedia technology and educational content and process provides convenience for individualization. The application of network technology and database technology make it easy for teachers and students to interact with distance teaching, interactive activities of students and evaluation of effect becomes easy, so that the principle of teaching students by specific characteristics can be realized.

Modern Educational Technology can Realize the Goal of Quality Education1) Modern educational technology is conducive to all students learning

Currently, the rapid development of social science and technology, new things and new knowledge is emerging, even if the students take life-long learning, it is impossible to master all of knowledge. Therefore, we must educate each student's potential to be effectively developed, while disseminating knowledge, focusing on training students' ability to learn and use knowledge. Modern educational technology can stimulate the development of students 'creative thinking, so that students can actively learn, cultivate the students' observation, thinking, practical ability, thus improving the learning efficiency.

2) Modern education technology can really achieve individualized teaching Quality education is for all, to promote each student has the opportunity to get fully developed education, classroom teaching should be not only for all, but also individualized. Traditional teaching methods are difficult to reach this, and modern educational technology can really solve this problem. Such as the use of multimedia network teaching methods can be set through the network curriculum functions, the difficulty of different topics were output to the different learning ability of students, students can also select their own teaching content for independent learning through the network course.

3) Modern educational technology is conducive to the development of non-intellectual factors Quality education attaches importance to the role of non-intellectual factors, advocate a happy teaching model. Modern education technology will introduce new teaching media in the actual teaching process, in addition to the traditional teaching of the text media, but also increased the voice, pictures, animation and video and other media together to stimulate the students senses, passing abstract teaching content through vivid audio-visual image to the students, and stimulate students' interest in learning, improve students learning enthusiasm. However, it should be noted that teachers should be based on the teaching content and teaching objectives, reasonably and scientifically choose and use a variety of modern media, especially in teaching to take modern teaching media and traditional media organically combined, to achieve the transfer of teaching information and optimization of feedback adjustment, to stimulate students' awareness of innovation, training students' innovation ability.

4) Modern educational technology provides favorable conditions for lifelong learning

In the development of students' quality, some aspects of quality such as professional skills, professional knowledge and skills, is to adapt to the students' requirement after graduation and take part in jobs, with the recent benefits. While other qualities such as moral standards, scientific and cultural foundation, professionalism, good health and good psychological quality and strong self-development ability, with long-term effect. Modern education technology can improve students' ability of autonomous learning and practical ability, for students to take the initiative to continue their own education, lay the foundation for lifelong education, is a useful means for life.

In short, modern educational technology plays an important role in all aspects of quality education, which has had a profound impact on the economy, politics, culture and way of life in modern society, which has made great changes in our educational system. Therefore, in order to truly achieve quality education, we should be flexible in the education process of using modern educational technology, and should pay attention to in-depth study on modern education technology. 
Through the scientific use of modern educational technology to explore the practical education for China's teaching model, to promote the further implementation of quality education.

\section{References}

[1] Sun Yingying, Zhang Chunsu, Lu Fang. Study on the cultivation of digital media technology ability of students in normal universities. Journal of Educational Technology and Equipment, 2014 (24) 95-96

[2] Sun Yingying. Education information technology exploration and practice [J]. Education and Occupation, 2012 (11) 163-164 